\title{
Pawel Gliniak
}

Uniwersytet Ekonomiczny we Wrocławiu

e-mail: gliniak.pawel@gmail.com

\section{PROBLEM NIERÓWNOŚCI DOCHODOWYCH I UBÓSTWA W WIELOETNICZNYM SPOLECZEŃSTWIE MALEZJI}

\section{INCOME INEQUALITY AND POVERTY PROBLEM IN MULTIETHNIC POPULATION OF MALAYSIA}

DOI: $10.15611 /$ sie.2015.2.03

JEL Classification: O21, I32, J15

Streszczenie: Celem artykułu jest analiza problemu nierówności dochodowych oraz ubóstwa wśród grup etnicznych Malezji. Rząd, mimo zastanych uwarunkowań historycznych, społecznych i gospodarczych, które pozostawili po sobie brytyjscy kolonialiści, sprawnie rozwiązał tę kwestię. Osiągnął to dzięki faktycznej koncentracji na zagadnieniu w trakcie implementacji długoterminowych programów rozwojowych, które zapoczątkowano w latach 70. Bezpośrednią przyczyną wdrożenia tychże programów był wybuch przemocy w 1969 r. skierowany przeciw majętniejszym Chińczykom. Współcześnie Malezję można uznać za przykład kraju, który sprawie poradził sobie z redukcją zarówno nierówności, jak i ubóstwa przy osiąganiu jednocześnie wysokiego wzrostu gospodarczego. Należy jednak podkreślić, że w trakcie wyrównywania różnic dochodowych, na przestrzeni lat, między Bumiputera a pozostałymi grupami etnicznymi zwiększyły się nierówności polityczne i społeczne. Współcześnie oddziałują one negatywnie na ekonomię i populację Malezji oraz mają wpływ na polityczną destabilizację państwa.

Słowa kluczowe: Malezja, ubóstwo, nierówności dochodowe, grupy etniczne Malezji.

Summary: The objective of this article is to analyze income inequality and poverty issue among ethnic groups in Malaysia. The government in spite of the historic, social and economic determinants inherited from British colonists, has managed this problem efficiently. This was achieved thanks to actual focus on the matter, during the long term development programs realization since the early $70 \mathrm{~s}$. These programs' implementation caused an immediate outbreak of violence targeted to the wealthiest Chinese in 1969. Nowadays Malaysia can be an example of the country that is managing successfully with inequality and poverty reduction together with the high economic growth. It has to be highlighted that during the decades of income inequality elimination between Bumiputera and other ethnic groups, the political and social inequalities raised. Presently, they have an effect on Malaysian economy and population and also impact the country destabilization.

Keywords: Malaysia, poverty, income inequalities, ethnic groups of Malaysia. 


\section{Nierówności ekonomiczne, ujęcie teoretyczne}

Współcześnie dokonuje się analizy czterech typów nierówności: politycznych, wobec prawa, społecznych i ekonomicznych. Według T. Nagla tylko kwestie równości i nierówności ekonomicznych można zanalizować w sposób formalny ${ }^{1}$. Zaznacza on, że rzeczywista równość opiera się w największej mierze na kwestii ekonomicznej. Mimo tego, że instytucje, zarówno formalne, jak i nieformalne, mogą działać na rzecz zapewnienia jednostce danego poziomu równości politycznych, prawnych czy społecznych, to jednak współcześnie kwestia poziomu dochodów z pracy i kapitału powoduje realne różnice w statucie danej jednostki. Oznacza to, że zapewnienie równości ekonomicznej, m.in. w procesie diagnozy i redukcji nierówności, jest kluczowe do uzyskania równości w pozostałych wymiarach. T. Nagel zaznacza, że zgodnie z zasadą zmniejszającej się użyteczności marginalnej dla jednostek posiadających daną liczbę danych dóbr, wzrost ich liczby nie będzie miał takiej samej wartości jak dla kogoś, kto ma ich mniej lub nie posiada ich wcale². Twierdzi też, że redukcja nierówności może prowadzić m.in. do zaburzania równowagi rynkowej np. na rynku pracy, gdyż praca stanie się droższa, czy ograniczania wolności gospodarczej poprzez wprowadzenie przymusu przez instytucje formalne. Radykalne niwelowanie nierówności może w konsekwencji spowodować szkodę dla użyteczności całkowitej, pogorszyć sytuację całego społeczeństwa czy naruszać prawa jednostkiª

Badania S. Kuznetsa były jednymi z przełomowych dotyczących wpływu nierówności dochodowych na wzrost gospodarczy. Na podstawie analizy krajów rozwiniętych (USA, Niemiec i Wielkiej Brytanii) oraz rozwijających się (Puerto Rico, Indii i Sri Lanki) doszedł do wniosku, że wraz z szybkim wzrostem gospodarczym nierówności rosną, a ich spadek notuje się spontanicznie i naturalnie po osiągnięciu wysokiego stadium rozwoju przez gospodarkę danego państwa. Autor w swojej pracy wskazuje jednak na brak oraz niedoskonałość zdobytych danych ${ }^{4}$. Na podstawie m.in. tych badań niektórzy ekonomiści wychodzą więc z założenia, że nierówności nie stanowią problemu dla gospodarki. Według nich to najubożsi są beneficjantami wzrostu gospodarczego, gdyż przekłada się on na zwiększenie ogólnego standardu życia każdej jednostki w społeczeństwie ${ }^{5}$. Mimo że badania S. Kuznetsa były na swój sposób przełomowe, dziś są kwestionowane, głównie na przykładzie krajów Azji Wschodniej. K. Deininger i L. Squire zanalizowali korelację między współczynnikiem Giniego, a poziomem wzrostu gospodarczego. Wyłącznie w pięciu

\footnotetext{
${ }^{1}$ T. Nagel, Pytania ostateczne, Fundacja Aletheia, Warszawa 1997.

${ }^{2}$ Tamże, s. 135, 136.

${ }^{3}$ Tamże, s. 136, 137.

${ }^{4}$ S. Kuznets, Economic growth and income inequality, The American Economic Review 1955,
} vol. 45, no. 1, s. 26.

${ }^{5}$ W. Woźniak, Politycy szczebla centralnego i lokalne elity wobec kwestii dziedziczenia nierówności społecznych, praca doktorska, Uniwersytet Łódzki, Łódź 2011, http://dspace.uni.lodz.pl:8080/ xmlui/handle/11089/7125, s. 74. 
przypadkach taka zależność została wykazana ${ }^{6}$. Badania Banku Światowego z kolei wykazały zgodność z prawem Kuznetsa tylko w co dziesiątym przypadku? . T. Piketty twierdzi, że teoria Kuznetsa, według której nierówności ekonomiczne mogą się zmniejszać bez względu na wprowadzone polityki czy uwarunkowania poszczególnych społeczeństw, lecz wyłącznie ze względu na fazę zaawansowania kapitalizmu, jest nierealna. Docenić należy jednak pogłębioną pracę statystyczną, której dokonał autor ${ }^{8}$.

T. Piketty zaznacza, że nierówności ekonomiczne składają się z trzech elementów: nierówności dochodów z pracy, nierówności płynących z własności kapitału i czerpanych $z$ nich dochodów oraz relacji pomiędzy powyższymi wielkościami ${ }^{9}$. Do badania nierówności występujących na danym obszarze niezbędna jest analiza tych elementów na kilku poziomach: normatywnym, moralnym, ekonomicznym, społecznym i politycznym. Na dochody z pracy jednostki wpływają: mechanizm równowagi rynkowej, uzyskane wykształcenie i umiejętności oraz jakość całego systemu edukacji i instytucji publicznych ${ }^{10}$. Tymczasem na nierówności wynikające z posiadanego kapitału wpływają m.in. poziom oszczędności i inwestycji, legislacja dotycząca spadków i darowizn oraz rynki nieruchomości i finansowe ${ }^{11}$. T. Piketty zauważa, że dochody płynące z pracy mają wpływ na nierówności ekonomiczne dopiero od zakończenia I wojny światowej. Wcześniej bogactwo równało się praktycznie odziedziczonemu majątkowi, a dochody z pracy nie miały znaczącego wpływu na jego wzrost. Zmieniło się to po katastrofie społeczno-ekonomicznej, jaką przyniosły dwie wojny światowe i w konsekwencji przyczyniło się do redukcji nierówności $\mathrm{w}$ okresie powojennym ${ }^{12}$. Pozwoliło to na stworzenie klasy średniej. Jednakże nawet współcześnie nierówności płynące $\mathrm{z}$ dochodu z pracy są mniejsze niż te płynące z kapitału ${ }^{13}$.

Oprócz nierówności ekonomicznych autor tej pracy zajął się problemem redukcji ubóstwa. A. Sen wskazuje, że pomiar ubóstwa można przedstawić w dwójnasób. Jako identyfikację ludności ubogiej oraz agregację danych dotyczących osób żyjących w niedostatku, co pozwoli na uzyskanie ogólnego wskaźnika ubóstwa ${ }^{14}$. Wskazuje, że wyznaczanie stopy ubóstwa (poverty rate), a w przypadku Malezji również stopy skrajnego ubóstwa (hardcore poverty rate) oraz luki dochodowej nie

\footnotetext{
${ }^{6}$ W. Jastrzębska, M. Lechwar, Nierówności ekonomiczne i kapitał ludzki z perspektywy polskich obszarów przyrodniczo cennych, Nierówności Społeczne a Wzrost Gospodarczy nr 24, Uniwersytet Rzeszowski, Rzeszów 2012, s. 5.

${ }^{7}$ W. Woźniak, wyd. cyt., s. 74.

${ }^{8}$ T. Piketty, Kapitat w XXI wieku, Wydawnictwo Krytyki Politycznej, Warszawa 2015, s. 23-26.

${ }^{9}$ Tamże, s. 294.

${ }^{10}$ Tamże, s. 300.

${ }^{11}$ Tamże, s. 300, 301.

${ }^{12}$ Tamże, s. 294-303.

${ }^{13}$ Tamże, s. 301-308.

${ }^{14}$ A. Sen, Nierówności. Dalsze rozważania, Społeczny Instytut Wydawniczy Znak, Kraków 2000, s. 124
} 
jest wystarczające do pomiaru ubóstwa na danym obszarze. Jest to spowodowane tym, że te wskaźniki nie uwzględniają rozkładu dochodu wśród osób ubogich. Aby otrzymać obiektywny obraz ubóstwa i transferów zachodzących $\mathrm{w}$ grupie o najniższych dochodach, należy wziąć pod uwagę rozkład dochodów najuboższych ${ }^{15}$. Według A. Sena rządy będą koncentrowały się wyłącznie na grupie najmajętniejszych wśród biednych, gdyż w najłatwiejszy sposób można wydobyć ich spod linii ubóstwa ${ }^{16}$.

A. Sen zaznacza, że kwestie ubóstwa można rozpatrywać z dwóch perspektyw od strony opisowej oraz próby implementacji adekwatnej polityki, która ten problem ma zredukować. Wprowadzona polityka musi zawierać diagnozę oraz analizę zastanej na danym terenie sytuacji, a następnie dostosować narzędzia, którymi dysponuje państwo w ramach przewidzianego budżetu ${ }^{17}$.

Według A. Sena ubóstwo należy rozpatrywać jako niemożność osiągnięcia minimalnego, akceptowalnego poziomu podstawowych potrzeb, w tym potrzeb społecznych. Twierdzi on, że ubóstwo to brak możliwości osiągania dobrobytu z powodu niskich środków materialnych, a nie wyłącznie niski poziom dobrobytu ${ }^{18}$. Dlatego nie można utożsamiać ubóstwa z niskimi dochodami, zapominając o indywidualnym zróżnicowaniu analizowanych jednostek ${ }^{19}$. Autor wskazuje, że w przypadku analizy ubóstwa i nierówności, szczególnie w krajach rozwiniętych, nie powinno się mówić o tych problemach wyłącznie z perspektywy dochodu. W znacznej mierze zjawiska te zależą od konkretnych cech i okoliczności ${ }^{20}$.

M. Piotrowska wskazuje trzy filary służące redukcji ubóstwa: wzrost gospodarczy, rozwój społeczny oraz właściwe zarządzanie państwem (good governance) ${ }^{21}$. Instytucje ekonomiczne, społeczne, kulturowe czy polityczne mogą pozytywnie i negatywnie wpływać na wszystkie wymienione filary ${ }^{22}$. Regulacje prawne i prawa własności mogą dawać początek wzrostowi gospodarczemu niwelującemu ubóstwo. Z kolei instytucje ekonomiczne redukują ubóstwo absolutne poprzez intensyfikację wzrostu gospodarczego. Następnie bezpośrednio na rozmiar ubóstwa wpływają instytucje społeczne. Przyczyniają się one do redystrybucji środków w ramach społeczności, mogą niwelować skutki kryzysów oraz wzmacniają produktywność i uczestnictwo w życiu społeczno-gospodarczym najmniej zarabiających. Instytucje polityczne diagnozują problem oraz możliwości państwa do redukowania problemu ${ }^{23}$.

${ }^{15}$ Tamże, s. 126.

${ }^{16}$ Tamże, s. 128.

${ }^{17}$ Tamże, s. 130, 131.

${ }_{18}^{18}$ Tamże, s. 133.

${ }^{19}$ Tamże, s. 135.

${ }^{20}$ Tamże, s. 133, 134, 140.

${ }^{21}$ M. Piotrowska, Rola instytucji w redukowaniu ubóstwa, [w:] B. Klimczak (red.) Mikroekonomia i ekonomia instytucjonalna, Prace Naukowe Uniwersytetu Ekonomicznego we Wrocławiu nr 74, Ekonomia 3, Wydawnictwo Uniwersytetu Ekonomicznego we Wrocławiu, Wrocław 2009, s. 174.

${ }^{22}$ Tamże, s. 172.

${ }^{23}$ Tamże, s. 180. 
J. Rawls analizuje kwestie nierówności społecznych, wprowadzając do dyskursu zasadę deferencji. Zakłada ona, że porządek społeczny nie ma na celu zapewniania większych możliwości dla majętniejszych, jeżeli nie przynosi to pozytywnych efektów dla mniej majętnych. Roszczenia osób bogatszych są więc sprawiedliwe i uzasadnione, kiedy podnoszą poziom oczekiwań uboższych. Następnie uważa, że nierówności są dopuszczalne wtedy i tylko wtedy, kiedy ich redukcja pogorszyłaby sytuację całego społeczeństwa. Pogląd ten ma charakter bardzo egalitarny. Według niej należy opowiadać się za równą dystrybucją dóbr, jeśli nie istnieje sposób, aby polepszyć sytuację wszystkich zainteresowanych stron. Gdy jeden podmiot zyskuje względem drugiego, to ze społecznego punktu widzenia dalsze korzyści pierwszego podmiotu nie przynoszą pozytywnego impulsu dla ogółu społeczności ${ }^{24}$. J. Rawls powołuje się również na zasadę kompensacji, według której należy zrekompensować jednostkom niezasłużone nierówności, których przyczynami były m.in. urodzenie, wrodzone zdolności lub ich brak czy kwestie naturalne ${ }^{25}$.

W pracy autor analizuje nierówności za pomocą wskaźników syntetycznych, głównie współczynnika Giniego. Jest on podawany krytyce przez T. Piketty’ego i A. Sena. Głównym argumentem pierwszego jest łączenie danych dotyczących nierówności w sferze pracy i kapitału ${ }^{26}$. Tymczasem ich społeczne, polityczne i ekonomiczne uwarunkowania i oraz próba analizy są odmienne. Nierówności mają postać wielowymiarową, więc jednowymiarowe wskaźniki upraszczają analizowany pro$\mathrm{blem}^{27}$. A. Sen z kolei twierdzi, że składowe tego wskaźnika nie tworzą odpowiedniej bazy danych do analizy ubóstwa. Aby otrzymać klarowniejszy obraz, konieczne jest więc uwzględnienie rozkładu dochodów wśród najmniej zarabiających, czego współczynnik Giniego nie bierze pod uwagę ${ }^{28}$.

Współczynnik mimo swoich wad dalej jest najpopularniejszym narzędziem do analizy przedstawionego w pracy problemu. Korzysta z niego również Departament Statystyki Malezji, dlatego uzupełniając dane komentarzami i wnioskami, autor zdecydował się na korzystanie z powyższego współczynnika.

\section{Społeczno-ekonomiczna charakterystyka kraju}

Malezję tworzy heterogeniczna, wieloetniczna i wielowyznaniowa populacja. W 2010 r. kraj zamieszkiwało 28,3 mln osób ${ }^{29}$. Malezja liberalizuje swoją gospodarkę, jednak państwo pozostaje kluczowym graczem w najważniejszych sektorach: finansach, przemyśle wydobywczym, motoryzacyjnym czy lotniczym. Główne do-

\footnotetext{
${ }^{24}$ J. Rawls, Teoria sprawiedliwości, Wydawnictwo Naukowe PWN, Warszawa 1994, s. 107.

${ }^{25}$ Tamże, s. 144.

${ }^{26}$ T. Piketty, wyd. cyt., s. 301.

${ }^{27}$ Tamże, s. 327.

${ }^{28}$ A. Sen, wyd. cyt., s. 125.

${ }^{29}$ Department of Statistics Malaysia, Population Distribution and Basic Demographic Characteristic 2010, Putrayaja, 2011, s. 1.
} 
bra eksportowe kraju to produkty elektryczne i elektroniczne $(32,9 \%)$, produkty petrochemiczne $(9,2 \%)$ czy gaz LNG $(8,4 \%)^{30}$. Rząd jest dość aktywny na arenie międzynarodowej, będąc m.in. założycielem ASEAN oraz głównym zwolennikiem rozwoju wymiany handlowej w regionie. Kraj prowadzi również aktywną wymianę handlową z praktycznie każdym kontynentem, a jej największymi partnerami handlowymi są m.in.: Singapur $(13,4 \%)$, Chiny $(14,3 \%)$, kraje Unii Europejskiej $(9,9 \%)$, Japonia $(9,5 \%)$ czy USA $(8,1 \%)^{31}$. Malezja jest krajem, który od 1991 r. notuje stabilny, a zarazem wysoki wzrost gospodarczy ${ }^{32}$. Przewiduje się, że w okresie 2013-2017 gospodarka Malezji będzie rosnąć średnio o 5,5\% rocznie. Praktycznie od odzyskania niepodległości w 1957 r. gospodarka kraju jest sprawnie reformowana, a jej PKB w coraz mniejszym stopniu zależy od rolnictwa, a w coraz większym od sektora produkcyjnego i sektora usług, które stają się kluczowymi elementami rozwoju gospodarki.

Nierówności występujące w Malezji można analizować na kilku poziomach. Pierwszym z nich jest podział wschód - zachód. Jako zachód w tym przypadku rozumie się Półwysep Malajski, ze stolicą w Kuala Lumpur. Z kolei wschód kraju to leżące na północy wyspy Borneo stany Sarawak i Sabah oraz terytorium federalne Labuan.

Drugim poziomem jest analizowanie nierówności występujących pomiędzy stanami, które tworzą Federację Malezji. Stały i szybki wzrost gospodarczy, który notuje kraj, nie jest równo dystrybuowany pomiędzy terytoria kraju. Wiąże się to m.in. z rozwojem poszczególnych sektorów gospodarki w wybranych stanach.

Większość aktywności gospodarczej z naciskiem na sektor usług lub produkcję dóbr o dużej wartości dodanej skupia się w Selangorze, Kuala Lumpur czy Pinangu. Zaznaczyć należy, że pomimo rozwoju kraju i programów redukcji ubóstwa oraz nierówności rozwarstwienie pomiędzy poszczególnymi stanami nie zmniejszyło się. Niektóre regiony w dalszym ciągu pozostają niekwestionowanymi liderami gospodarczymi.

Kolejną osią analizy kraju pod kątem nierówności jest oś miasto - wieś. Od 1970 r., kiedy kraj zaczął notować szybszy rozwój przemysłu i sektora usług, tereny miejskie gwałtownie się rozwinęły. W ciągu czterech dekad procent populacji mieszkającej w miastach wzrósł z 27 do 71 . Jednakże redukcja ubóstwa na prowincji jest w dalszym ciągu jednym z priorytetów polityki rządu. Do tej pory można ją uznać za bardzo skuteczną, gdyż ubóstwo na prowincji spadło z poziomu 58,7\% w $1970 \mathrm{r}$. do 3,4\% w 2012 r. (tab. 1). Polityka redukcji ubóstwa na obszarach wiejskich ma swoje

${ }^{30}$ Malaysian External Trade Development Corporation, Top 10 Major Export Products 2014, http://www.matrade.gov.my/en/malaysia-exporters-section/33-trade-statistics/3184-top-10-major-export-products-2014 (13.09.2015).

${ }^{31}$ Zob. np. Bank Negara Malaysia, Malaysia's Total Trade by Market, http://www.bnm.gov.my/ files/publication/ar/en/2014/zcp07_table_A.12.pdf (13.09.2015).

${ }^{32} \mathrm{Z}$ wyjątkiem lat 1998 i 2009 ze względu na kryzysy gospodarcze. 
przyczyny polityczne. Na wsi właśnie, zdecydowana większość wyborców głosuje na rządzącą koalicję Barisan National ${ }^{33}$.

Tabela 1. Procentowy wskaźnik ubóstwa w Malezji z podziałem na grupy etniczne oraz tereny miejskie i wiejskie, 1970-2014

\begin{tabular}{|l|r|r|r|r|r|r|r|r|r|r|c|}
\cline { 2 - 12 } \multicolumn{1}{c|}{} & 1970 & 1976 & 1979 & 1987 & 1989 & 1995 & 1999 & 2004 & 2009 & 2012 & 2014 \\
\hline Malezja & 49,3 & 37,7 & 37,4 & 19,4 & 16,5 & 8,7 & 8,5 & 5,7 & 3,8 & 1,7 & 0,6 \\
\hline Bumiputera & 64,8 & 46,4 & 49,2 & 26,6 & 23 & 12,2 & 12,3 & 8,3 & 5,3 & 2,2 & 0,8 \\
\hline Chińczycy & 26,0 & 17,4 & 16,5 & 7,0 & 5,4 & 2,1 & 1,2 & 0,6 & 0,6 & 0,3 & 0,1 \\
\hline Obszary miejskie & 21,3 & 15,4 & 17,5 & 8,5 & 7,1 & 3,6 & 3,3 & 2,5 & 1,7 & 1,0 & 0,3 \\
\hline Obszary wiejskie & 58,7 & 45,7 & 45,8 & 24,8 & 21,1 & 14,9 & 14,8 & 11,9 & 8,4 & 3,4 & 1,6 \\
\hline
\end{tabular}

Źródło: Economic Planning Unit, Malaysia: 30 Years of Poverty Reduction, Growth and Racial Harmony, 2004, http://web.worldbank.org/archive/website00819C/WEB/PDF/MALAYS-2.PDF (13.09.2015).

Czwartym poziomem jest ocena nierówności ze względu na płeć. Nierówności $\mathrm{w}$ tym obszarze podyktowane były pierwotnie $\mathrm{m}$.in. nierównym dostępem do edukacji i niektórych, lepiej płatnych zawodów. Dziś uwarunkowane jest to często relacją między religią, głównie wyznawanym przez Malajów islamem, a płciowością.

Ostatnią, ale kluczową z przyczyn nie tylko gospodarczych, ale i społeczno-politycznych, jest analiza nierówności ze względu na pochodzenie etniczne. Malezja, ze względu na uwarunkowania historyczne, jest krajem wieloetnicznym, a jej populacja składa się z ponad stu grup etnicznych, spośród których trzy są zdecydowanie największe. Grupami tymi są Malajowie, których nazywa się również Bumiputera, Chińczycy oraz Hindusi. Ten poziom analizy nierówności będzie kontynuowany w dalszej części pracy.

\section{Wieloetniczna populacja Malezji}

\subsection{Bumiputera}

Bumiputera lub Peribumi (syn ziemi) to malajski termin opisujący Malajów oraz ludy autochtoniczne zamieszkujące tereny współczesnej Malezji. Malajowie są aktualnie najliczniejszą grupą zamieszkującą Federację, tworząc 68\% społeczeństwa. Według analiz do 2020 r. liczba Malajów ma wynosić 31,6 mln osób. Malajowie przybyli na tereny półwyspu około XIX w. z pobliskich wysp: Sumatry, Sulawesi

${ }^{33}$ Zob. np. Associated Press, Malaysia's election result exposes divided country, CBCNews, 2013, http://www.cbc.ca/news/world/malaysia-s-election-result-exposes-divided-country-1.1344840 (13.09.2015); A dangerous result, The Economist 2013, http://www.economist.com/news/leaders/21577390-after-tainted-election-victory-najib-razak-needs-show-his-reformist-mettle-dangerous (13.09.2015). 
i Riau. Malajowie, zgodnie z literą malezyjskiego prawa, są muzułmanami. Tym samym islam jest najczęściej praktykowaną religią w kraju.

Malajowie rozsiani są po całym kraju, jednak najliczniejszą grupę stanowią w stanach Terangannu, Kelantan oraz Perlis. W artykule 160 Konstytucji Federacji Malezji zawarta jest prawna definicja tej grupy: Malaj oznacza osobę, która wyznaje islam, posługuje się językiem malajskim, stosuje się do malajskich obyczajów oraz przed dniem uzyskania niepodległości urodziła się na terenie Federacji lub w Singapurze, lub jeden z jej rodziców urodził się na terenie Federacji, lub w Singapurze, lub po tym dniu zamieszkiwała Federację lub Singapur ${ }^{34}$.

Autochtoniczne ludy dzisiejszej Malezji dzieli się na dwie grupy. Orang Asli (ludzie natury) zamieszkują Półwysep Malajski, m.in. tereny Cameron Highlands i w odróżnieniu do Malajów nie są muzułmanami. Populacja Orang Asli wynosi ok. 178 tys. osób, co stanowi ok. 0,5\% populacji.

W oficjalnych statystykach Malajowie, Orang Asli oraz grupy tubylcze zamieszkujące Sarawak i Sabah figurują jako Bumiputera. Z tego powodu ciężko otrzymać jednoznaczne statystyki dotyczące sytuacji ekonomicznej grup autochtonicznych. Bez wątpienia jednak Orang Asli są grupą najuboższą. W 2010 r. wskaźnik ubóstwa pośród tej grupy wynosił $76,9 \%$, a skrajnego ubóstwa $35,2 \%{ }^{35}$ przy średniej krajowej dla tego roku wynoszącej $3,8 \%$. Ocenia się, że sytuacja tej grupy ulega stałemu pogorszeniu, a jako grupa słabiej wykształcona narażona jest na dużą presję polityczną. Ze względu na to, że ta druga grupa stanowi ok. $0,5 \%$ populacji kraju, w tej pracy termin Bumiputera będzie używany zamiennie z terminem Malajowie.

\subsection{Malezyjscy Chińczycy}

Malezyjscy Chińczycy są trzecią najliczniejszą chińską diasporą na świecie po Tajlandii i Indonezji. Zamorscy Chińczycy, szczególnie ci, którzy osiedlili się w Azji Południowo-Wschodniej, byli silnie podzieleni i zróżnicowani na wielu poziomach. Główne różnice to dialekt lub język, poziom wykształcenia, terytorium, z którego pochodzili przodkowie, preferencje w wyborze profesji czy zapatrywania polityczne.

Głównymi grupami, które zdominowały Malezję, są Chińczycy Hokkien, Teochew, Kantończycy, Hajnańczycy i Hakka.

Przed odzyskaniem niepodległości (dane z 1957 r.) tworzyli oni 38,4\% ludności tego $\mathrm{kraju}^{36}$. Mimo rosnącej populacji, procentowy udział w strukturze społeczeństwa zmniejsza się i w 2013 r. osiągnął 24\%. Wiąże się to z rosnącą liczbą ludno-

${ }^{34}$ Tłumaczenie własne na podstawie Undang-Undang Malaysia, Perlembagaan Persekutuan, 2006, http://www.jac.gov.my/images/stories/akta/perlembagaanpersekutuan.pdf (19.02.2016).

${ }^{35}$ T. Masron, M. Fujimaki, I. Norhasimah, Orang Asli in peninsular Malaysia: Population, spatial distribution and socio-economic conditions, Journal of Ritsumeikan Social Sciences and Humanities 2013, vol. 6, s. 75.

${ }^{36}$ Zob. np. B. Khoo, Ethnic Structure, Inequality and Governance in the Public Sector Malaysian Experiences, Democracy, Governance and Human Rights Programme Paper 20, 2005, http://www.un- 
ści malajskiej, dzięki najwyższemu wśród największych grup etnicznych wskaźnik dzietności. Malezyjscy Chińczycy koncentrują się na zachodzie półwyspu Malajskiego, m.in. w stanach Penang i Johor czy w Kuala Lumpur. Jednak liczna grupa zamieszkuje również północne Borneo, szczególnie miasta Kota, Kinabalu i Kuching.

Obecnie Chińczycy są najbogatszą spośród grup etnicznych kraju. Ich przewaga ekonomiczna w stosunku do innych grup, a szczególnie liczniejszych Malajów, oraz dysproporcje ekonomiczne były i są powodem tarć społeczno-politycznych praktycznie od uzyskania niepodległości w 1957 r. Do dziś kwestia etniczna wykorzystywana jest w polityce tego kraju. Zdominowany przez Malajów rząd ma w zwyczaju podkreślać niesłusznie, co pokazuje historia, jakoby Chińczycy byli tylko gośćmi w kraju, którego gospodarzem są Malajowie.

\subsection{Malezyjscy Hindusi}

Trzecią najliczniejszą grupą zamieszkującą kraj są Hindusi. W Malezji tworzą oni największą społeczność Hindusów mieszkających poza Indiami. Stanowią 7,2\% społeczeństwa. Największą grupę tworzą w stanach Negari Sembilan, Selangorze oraz Peraku. $85 \%$ Malezyjskich Hindusów to Tamilowie, a prawie $60 \%$ z nich jest potomkami pracowników plantacji sprowadzonych do Malajów Brytyjskich przez kolonizatorów. Hindusi są często pomijaną grupą etniczną Malezji. W stosunku do Chinczyków nie mają siły ekonomicznej, a w stosunku do Malajów politycznej. Niektórzy publicyści uważają wręcz, że są oni dyskryminowani w związku z prowadzaną od lat 70. polityką skoncentrowaną wyłącznie na Bumiputera ${ }^{37}$. Wraz z dyskryminacją ekonomiczną przez m.in praktyczne wykluczenie z partycypowania w majątku kraju Hindusi dyskryminowani są również społecznie. Zdominowany przez większość muzułmańską rząd utrudnia wyznawcom hinduizmu stawianie świątyń oraz pod pretekstem rozwijania infrastruktury rozbiera postawione przed kilkoma pokoleniami ${ }^{38}$. Według danych raportu Malaysian Indian Minority and Human Rights Violations z 2008 r. Hindusi są też grupą najczęściej dyskryminowaną przez policję - co wydaje się nieprawdopodobne, $90 \%$ ofiar policji to Hindusi, a ich zatrudnienie w służbie cywilnej spadło z $50 \%$ w latach 60 . do 1\% współcześnie ${ }^{39}$.

risd.org/80256B3C005BCCF9/\%28httpAuxPages\%29/19309421DF6D65D3C12570FA00392E12/\$file/Khoo\%20\%28small\%29.pdf (31.03.2015).

${ }^{37}$ D. Lahiri, Malaysian Indian Community: Victim of 'Bumiputera' Policy, ORF Issue Brief 2008, no. 12 , s. $1-8$.

${ }^{38}$ Tamże.

${ }^{39}$ Malaysian Indian Minority and Human Rights Violations Annual Report 2008, http://www.indianmalaysian.com/MalaysianIndianReport.pdf (13.09.2015). 


\section{Uwarunkowania społeczno-historyczne nierówności dochodowych w Malezji}

Społeczna i ekonomiczna równowaga pomiędzy grupami etnicznymi była ważnym elementem polityki w Malezji praktycznie od uzyskania niepodległości w 1957 r., a może nawet za czasów brytyjskich. Malaje Brytyjskie cechowały się gospodarką dualną, podzieloną na sektory tradycyjny i nowoczesny. Sektor tradycyjny, czyli rolnictwo oparte na małej skali produkcji, z małymi organizacjami, skoncentrowany był w regionie zdominowanym przez Malajów (stany Pahang, Terangganu, Kelantan, Kedah i Perlis). Z kolei nowoczesne rolnictwo zlokalizowane było w zachodniej części półwyspu. Tereny te zamieszkiwali Chińczycy ${ }^{40}$. Od początku tworzyło to dysproporcje zarobkowe między grupami etnicznymi.

Rządząca od uzyskania niepodległości koalicja Partii Sojuszu (Parti Perikatan; The Alliance Party $)^{41}$ zrzeszała partie reprezentujące wszystkie największe grupy etniczne Malezji. Miało to zapewnić stabilizację polityczną w kraju. Podległe Brytyjczykom Malaje cechowały się wysokim poziomem nierówności między grupami etnicznymi oraz wysokim poziomem ubóstwa. Sytuacja nie uległa znaczącej poprawie również w pierwszej dekadzie niepodległości. Kraj oparł swój rozwój na zasadach leseferyzmu. W latach 60. Malezja notowała bardzo wysoki wzrost gospodarczy, szczególnie w przemyśle. Przemysł rósł z prędkością 11,5\% rocznie, a cały wzrost PKB w okresie 1960-1970 wynosił 6,4\% średniorocznie. Niestety, ten błyskotliwy wynik nie przełożył się na zmniejszenie bezrobocia, ubóstwa czy nierówności. W 1962 r. bezrobocie na Półwyspie Malajskim wynosiło 6,0\%, aby wzrosnąć do $8,0 \% \mathrm{w} 1970 \mathrm{r}$. W tym też roku stopa ubóstwa wyniosła 49,3\% i była najwyższa wśród krajów Azji. Wzrosły również nierówności. W latach 1957-1958 współczynnik Giniego wynosił 0,41, a w 1970 r. 0,5142.

Z. Osman i H. Shahiri wskazują, że w czasie pierwszych lat niezależnej Malezji przynależność etniczna decydowała o rodzaju zatrudnienia. Handel oraz przemysł, a także wszystkie nowoczesne sektory gospodarki zlokalizowane w obrębie miast były praktycznie zmonopolizowane przez Chińczyków. Z kolei stanowiący większość społeczeństwa Malajowie zatrudnieni byli w dalszym ciągu w nisko dochodowym rolnictwie, a mała część tej grupy piastowała urzędy publiczne, podobnie jak Hindusi, którzy co prawda sporadycznie pracowali w usługach publicznych, jednak głównie zatrudnieni byli na plantacjach ${ }^{43}$.

${ }^{40}$ A.J. Abdullah, H. Doucouliagos, E. Manning, Are regional incomes in Malaysia converging?, Papers in Regional Science 2015, vol. 94, s. 69-94.

${ }^{41}$ Przemianowana w 1973 r. na Barisan Nasional.

${ }^{42}$ Z. Osman, H. Shahiri, Ethnic and gender inequality in employment during New Economic Policy, Institutions and Economics 2014, vol. 6, no. 1, s. 58, 59.

${ }^{43}$ Tamże, s. 59. 
Przytaczany powyżej rok 1970 był kluczowy dla gospodarki Federacji. Na fali pogłębiających się nierówności, ubóstwa oraz braku równowagi w zatrudnieniu ze względu na kwestie rasowe, w maju 1969 r. wybuchły zamieszki. Większość, którą stanowili Malajowie, sprzymierzyła się przeciwko majętniejszym Chińczykom ${ }^{44}$. Zamieszki były skutkiem społeczno-gospodarczego problemu ciągnącego się przez dekady. Na wybuch zamieszek wpływ miały głównie kwestie gospodarcze, ale również polityczne. Chińczycy, którzy tworzyli komunistyczny ruch oporu najpierw przeciw Brytyjczykom, a następnie, w trakcie II wojny światowej, przeciw Japończykom, już po zakończeniu działań wojennych byli m.in. oskarżani o sprzyjanie komunistycznym Chinom. Po zamieszkach z 1969 r., w których śmierć poniosło ok. 200 osób, a 6000 pozbawionych zostało dachu nad głową, rząd zdecydował się na wprowadzenie Nowej Ekonomii Politycznej (Dasar Ekonomi Baru, DEB).

\section{Programy redukcji ubóstwa i nierówności}

Rząd Malezji od 1970 r., razem z innymi krótko- i średnioterminowymi programami i politykami, przeprowadził trzy długoterminowe plany rozwojowe: I Outline Perspective Plan, tzw. New Economic Policy (1970-1990), II Outline Perspective Plan, tzw. New Developmental Policy (1991-2000) oraz III Outline Perspective Plan, tzw. National Vision Policy - Vision 2020 (2001-2010).

Priorytetem wprowadzonych planów było zapewnienie równości dochodowych, społecznych i politycznych obywatelom przy utrzymaniu wysokiego wzrostu gospodarczego. Realizacja wymienionych planów odbywała się przy wsparciu 5-letniego planowania gospodarczego.

\subsection{Nowa Polityka Ekonomiczna (DEB)}

Pokłosiem zamieszek z 1969 r. było wprowadzenie w 1970 r. Nowej Polityki Ekonomicznej (DEB). Głównymi celami DEB-u, którego horyzont czasowy zaplanowany był na 20 lat, były redukcja ubóstwa wśród mieszkańców, bez względu na grupę etniczną, oraz restrukturyzacja społeczeństwa, mająca na celu eliminację łączenia pochodzenia etnicznego z przyszłym zawodem lub aktywnością gospodarczą ${ }^{45}$. Aby osiągnąć założone cele, rząd zdecydował się m.in. na dywersyfikację sektora rolniczego, intensyfikację wykorzystania zasobów naturalnych oraz zmianę polityki przemysłowej na zorientowaną proeksportowo ${ }^{46}$. Malezja porzuciła leseferystyczną politykę, którą realizowała od lat 50., na rzecz aktywniejszej interwencji przez wpro-

${ }^{44}$ A.J. Abdullah i in., wyd. cyt., s. 74.

${ }^{45}$ K. Jomo, The New Economic Policy and Interethnic Relations in Malaysia, Identities, Conflict and Cohesion Program Paper 2004, no. 7, United Nations Research Institute for Social Development, s. 3.

${ }^{46}$ H. Ragayah, Income inequality in Malaysia, Asian Economic Policy Review 2008, vol. 3, no. 1, s. 122. 
wadzenie licencji, kwot czy cen regulowanych. Rząd tworzył strefy wolnego handlu oraz wspierał zakładanie licencjonowanych warsztatów i fabryk. Implementowana polityka miała na celu zachęcenie producentów do eksportu wytwarzanych dóbr ${ }^{47}$.

Wprowadzona polityka w dwójnasób koncentrowała się na nierównościach dochodowych wśród grup etnicznych. Po pierwsze, modernizacji miały ulec obszary wiejskie, które w zdecydowanej większości zamieszkiwane były przez Bumiputera. Po drugie, aby zapewnić wysoki, ale i stabilny wzrost w miastach, musiano stworzyć warunki do rozwoju malajskiej społeczności i zwiększyć partycypację tej grupy w sektorze przemysłu i handlu. Analizując kwestie wyrównywania szans Bumiputera w społeczeństwie Malezji, pamiętać należy, że intencją DEB-u było osiągnięcie tych celów bez straty dla innych grup etnicznych, w szczególności Chińczyków, a finansowanie tej ,inżynierii społecznej” miało być zapewnione dzięki prognozowanemu wzrostowi gospodarczemu.

DEB uznany został za spory sukces rządzącej koalicji. Przedstawiają to twarde dane. Jednak według K. Jomo powinno brać się poprawkę na oficjalne dane rządowe, szczególnie te z lat 60 . i 70 . Jednakże, ogólny wynik wyraźnie obrazuje sukces przeprowadzonej polityki ${ }^{48}$.

Ubóstwo zostało zredukowane, według różnych danych, z poziomu 49,3 lub $56,7 \%$ w 1970 r. do $17,1 \%$ w 1990 r. (dla samego półwyspu nawet do poziomu $16,5 \%)^{49}$. Średni miesięczny dochód gospodarstw domowych wzrósł znacznie wśród wszystkich grup etnicznych (rys. 1), jednak największy przyrost został zanotowany wśród Bumiputera z poziomu 264 RM w 1970 r. do 1169 RM w 1990 r. Zawęziły się również różnice $\mathrm{w}$ dochodzie gospodarstw domowych między Malajami a innymi grupami etnicznymi. W stosunku do malezyjskich Chińczyków wskaźnik ten zmniejszył się z poziomu 2,29 w 1970 r. do 1,74 w 1990 r. ${ }^{50} 49$ (tab. 2).

Tabela 2. Mediana dochodu gospodarstw domowych w Malezji z uwzględnieniem grup etnicznych oraz stosunek dochodu między grupami (RM)

\begin{tabular}{|l|c|c|c|c|c|c|c|c|c|c|c|}
\cline { 2 - 13 } \multicolumn{1}{c|}{} & 1970 & 1976 & 1979 & 1987 & 1989 & 1995 & 1999 & 2004 & 2009 & 2012 & 2014 \\
\hline Malezja & 166 & 308 & 429 & 738 & 816 & 1,377 & 1,704 & 2,211 & 2,830 & 3,626 & 4,585 \\
\hline Bumiputera & 120 & 233 & 338 & 613 & 679 & 1,143 & 1,423 & 1,862 & 2,531 & 3,282 & 4,214 \\
\hline Chińczycy & 268 & 480 & 656 & 1,063 & 1,176 & 2,010 & 2,486 & 3,089 & 3,631 & 4,643 & 5,708 \\
\hline Hindusi & 194 & 360 & 521 & 805 & 890 & 1,553 & 1,969 & 2,469 & 2,836 & 3,676 & 4,627 \\
\hline B/C & 2,23 & 2,06 & 1,94 & 1,73 & 1,73 & 1,76 & 1,75 & 1,66 & 1,43 & 1,41 & 1,35 \\
\hline B/H & 1,62 & 1,55 & 1,54 & 1,31 & 1,31 & 1,36 & 1,38 & 1,33 & 1,12 & 1,12 & 1,10 \\
\hline
\end{tabular}

B - Bumiputera, C - malezyjscy Chińczycy, $\mathrm{H}$ - malezyjscy Hindusi.

Źródło: obliczenia własne oraz Economic Planning Unit, wyd. cyt.

\footnotetext{
${ }^{47}$ Tamże, s. 122, 123.

${ }^{48}$ K. Jomo, wyd. cyt., s. 4.

${ }^{49}$ Tamże.

${ }^{50}$ Tamże, s. 6, 7.
} 


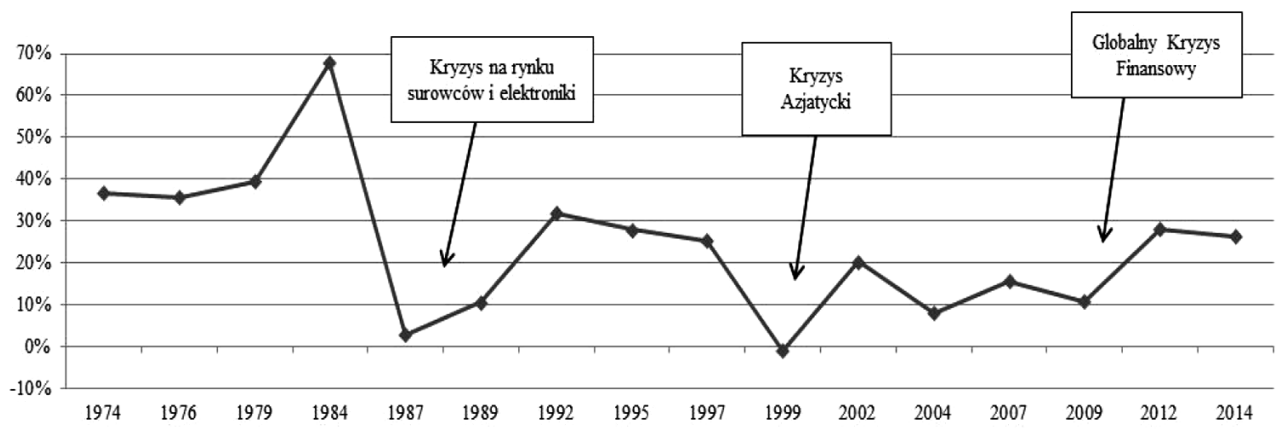

Rys. 1. Rokroczny procentowy przyrost mediany dochodu gospodarstwa domowego w Malezji, 1970-2014

Źródło: opracowanie własne na podstawie Economic Planning Unit, wyd. cyt.

Analizując DEB, nie należy zapominać o innych czynnikach, które miały wpływ na rozwój społeczno-ekonomiczny kraju w tym okresie. Do redukcji ubóstwa na terach wiejskich, zamieszkiwanych głównie przez Bumiputera, przyczyniły się takie zjawiska, jak wzrost kwalifikacji pracowników, wzrost produktywności czy spadek bezrobocia ze względu na migrację do miast i rozwój rynku pracy dzięki powiększeniu sektora przemysłowego i publicznego, co przełożyło się na zwiększenie wynagrodzeń $^{51}$. K. Jomo zaznacza, że do niwelowania poziomu ubóstwa przyczynił się wzrost produktywności w rolnictwie, czego głównym beneficjentem byli rolnicy posiadający ziemie lub plantacje. DEB w swoich założeniach praktycznie nie zwrócił się w stronę wiejskich pracowników najemnych czy pracowników fizycznych sektora wydobywczego. Faktycznie ich płace wzrosły, jednak przyczyniły się do tego wspomniany wzrost produktywności oraz spadek bezrobocia. $Z$ drugiej strony, analizując dochód gospodarstw domowych, należy pamiętać o znacznej dzietności wśród malezyjskich kobiet, szczególnie Bumiputera, co spowodowało brak realnego wzrostu bogactwa wśród nich ${ }^{52}$. Uważa się również, że w pierwszym okresie DEB polityka redukcji ubóstwa m.in. poprzez dotowanie cen ryżu przyczyniła się do zysków wielkich posiadaczy ziemskich, co zwiększyło nierówności wśród samych Malajów ${ }^{53}$.

Mimo że DEB nie zakładał bezpośredniego oddziaływania na całą gospodarkę i wszystkich mieszkańców, to pośrednio pozytywnie wpływał na całe społeczeństwo i ekonomię kraju. Rozwinęła się infrastruktura oraz podniosła się jakość usług publicznych. Cel, aby Malajowie partycypowali w 30\% majątku kraju, nie został osiągnięty. W 1970 r. byli właścicielami wyłącznie 2,4\% kapitału, przy 27,2\% Chiń-

\footnotetext{
${ }^{51}$ H. Ragayah, wyd. cyt., s. 125, 126.

${ }^{52}$ K. Jomo, wyd. cyt., s. 8.

${ }^{53}$ Tamże, s. 17, 18.
} 
czyków i 63,4\% zagranicznych inwestorów. Wyraźny spadek udziału zagranicznych inwestorów w 1990 r. do 25,4\% przyczynił się do zwiększonego wpływu Bumiputera i malezyjskich Chińczyków $\left(19,1\right.$ oraz 55,3\%) ${ }^{54}$. Sytuacja, w której dzięki szeroko pojętej ingerencji państwa udział majątków Malajów rósł, rodziła też patologie. Wiele MŚP, głównie w sektorach budowlanym i nieruchomości, nazywanych Ali-Baba, opierało się na zasadach, w których malajski partner odpowiedzialny był wyłącznie za reprezentowanie firmy i otrzymanie licencji od rządu, kiedy strona chińska wdrażała cały pomysł. Z tego względu z biegiem czasu Chińczycy przejmowali kierownictwo nad całą firmą ${ }^{55}$.

Struktura zatrudnienia również uległa zmianie. W 1970 r. Bumiputera byli niedoreprezentowani w każdym z rodzajów zatrudnienia z wyjątkiem rolnictwa, aby już w 2000 r. zwiększyć proporcję zatrudnienia w każdej z grup zawodowych. Należy zaznaczyć, że jakkolwiek proporcje w zatrudnieniu wyrównały się, to Malajowie dalej byli wykluczeni z najlepiej płatnych posad. Partycypacja w ośmiu najbardziej dochodowych zawodach wzrosła, co prawda, z 4,9\% w 1970 r. do 29,0\% w 1990 r., jednak biorąc pod uwagę, że tworzyli wtedy ok. 60\% populacji, wynik dalej był daleki od pożądanego ${ }^{56}$.

Bezsprzeczny wpływ na redukowanie nierówności miało zapewnienie dostępu do edukacji dla każdej z grup etnicznych w trakcie DEB, ze szczególnym uwzględnieniem Bumiputera. Wdrożono dwa typy programów edukacyjnych. Pierwszy miał na celu zapewnienie podniesienia kwalifikacji oraz jak najszybszego przeszkolenia Malajów, a także utworzenie i rozwinięcie Masyarakat Perdagangan dan Perindustian Bumiputera (MPPB). Celem MPPB było wspieranie rządu w jak najefektywniejszej alokacji kontraktów, licencji czy kwot dla przedsiębiorstw, których właścicielami byli Bumiputera. Dla nich również przeznaczone były nisko oprocentowane kredyty mieszkaniowe oraz pożyczki celowe na rozwój przedsiębiorstw. Drugi koncentrował się na zapewnieniu wykształcenia na wszystkich poziomach ${ }^{57}$. Rząd zdecydował się wprowadzić kwoty na publicznych uczelniach wyższych, które miały zapewnić udział Malajów w najwyższym stopniu edukacji. W 1985 r. liczba studentów Bumiputera na akredytowanych stanowiskach wynosiła 67\%. Nadreprezentacja tej grupy doprowadziła do tego, że inne grupy etniczne zdecydowały się na posyłanie uczniów do prywatnych szkół wyższych. Należy też dodać, że rząd oferował hojne stypendia zagraniczne dla tej grupy. K. Jomo zaznacza, że zjawisko kwotowania na uczelniach doprowadziło do sytuacji, w której bezrobocie wśród najwyżej wykształconych zwiększyło sięers.

\footnotetext{
54 Tamże, s. 11.

${ }^{55}$ E. Gomez, Affirmative action and enterprise development in Malaysia: The New Economic Policy, Business Partnership and Inter-ethnic Relations Kajian Malaysia 2003, vol. 21, no. 1/2, s. $64,65$.

${ }^{56}$ K. Jomo, wyd. cyt., s. 15, 16.

${ }^{57}$ H. Ragayah, wyd. cyt., s. 125.

${ }^{58}$ K. Jomo, wyd. cyt., s. 16, 17.
} 


\subsection{Nowa Polityka Rozwojowa (DPN) oraz Polityka Wizji Narodowej (DWN)}

Kiedy w 1990 r. przewidziany na dwie dekady DEB dobiegł końca, rząd wprowadził kolejny plan rozwojowy sformułowany na podstawie dokumentu Nowa Polityka Rozwojowa (Dasar Pembanunan Negara, DPN). W zakresie redukcji ubóstwa i restrukturyzacji społeczeństwa pod kątem dalszego wyrównywania szans Bumiputera DPN było praktycznie kontynuacją DEB. W dalszym ciągu nierówności dochodowe miały być wyrównywane przez zapewnienie partycypowania w majątku kraju, edukacji czy zatrudnieniu w dochodowych branżach gospodarki. Jednakże nowy plan kładł większy nacisk na walkę z relatywnym ubóstwem oraz nierównościami dochodowymi nie tylko pomiędzy grupami etnicznymi, ale wewnątrz nich. Więcej uwagi poświęcono również roli MPPB. Co prawda, założenie osiągnięcia 30\% majątku kraju w rękach Bumiputera pozostawiono, jednak bez konkretnych ram czasowych.

Jako że DPN przewidziano tylko na jedną dekadę (1991-2000), już w 2000 r. powołano Politykę Wizji Narodowej (DWN) (2001-2010). W zakresie niwelowania różnic dochodowych oraz poziomu ubóstwa pierwszy z planów nie przewidywał rewolucyjnych rozwiązań. Kontynuował wręcz strategię przewidzianą w poprzednich planach. Podobnie jak DPN przewidywał większą rolę sektora prywatnego na rzecz interwencji państwa. Instytucje publiczne i rząd miały stanowić wyłącznie wsparcie oraz uzupełnienie dla wolnego rynku. Trzeba jednak wziąć poprawkę na lata 1997 i 1998, czyli azjatycki kryzys finansowy. Wtedy rząd zdecydował się na większą interwencję, szczególnie w porównaniu z sąsiadami: Tajlandią i Indonezją, czym zapewnił sobie sukces.

Aby móc dostosowywać założenia do zmieniających się okoliczności, rząd przewidział plany tylko na 10 lat. W związku z tym osiągnięcia obu planów będą analizowane razem. Przez ten okres praktycznie całkowicie udało się zredukować poziom ubóstwa, który w 1989 r. wynosił 16,4\%, a w 2012 r. tylko 1,7\%. Niestety w dalszym ciągu był on najwyższy wśród Bumiputera i w 2012 r. wynosił 5,3\%. Zanotowano również minimalny spadek nierówności wewnątrz grup etnicznych (rys. 2), przyrost mediany miesięcznego dochodu gospodarstwa domowego z 816 RM w 1989 r. do 3624 RM w 2012 r. oraz zmniejszenia relacji dochodowych między grupami etnicznymi.

W czasie DPN zmieniła się również struktura zatrudnienia w trzech sektorach gospodarki. Pod koniec DEB 36,7\% Bumiputera pracowało w rolnictwie, 21,2\% w usługach i służbie publicznej, a 17,0\% w przemyśle. Już w 2000 r. 18,2\% pracowało $\mathrm{w}$ rolnictwie, $25,0 \% \mathrm{w}$ usługach, a $26,3 \% \mathrm{w}$ przemyśle, co obrazuje wielki odpływ pracowników z rolnictwa do przemysłu. Od 1999 r. Malajowie stanowią również największą grupę wśród lekarzy, chirurgów i weterynarzy oraz drugą najliczniejszą grupę, po Chińczykach, wśród innych profesji ${ }^{59}$.

\footnotetext{
${ }^{59}$ Economic Planning Unit, wyd. cyt., s. 15, 16.
} 


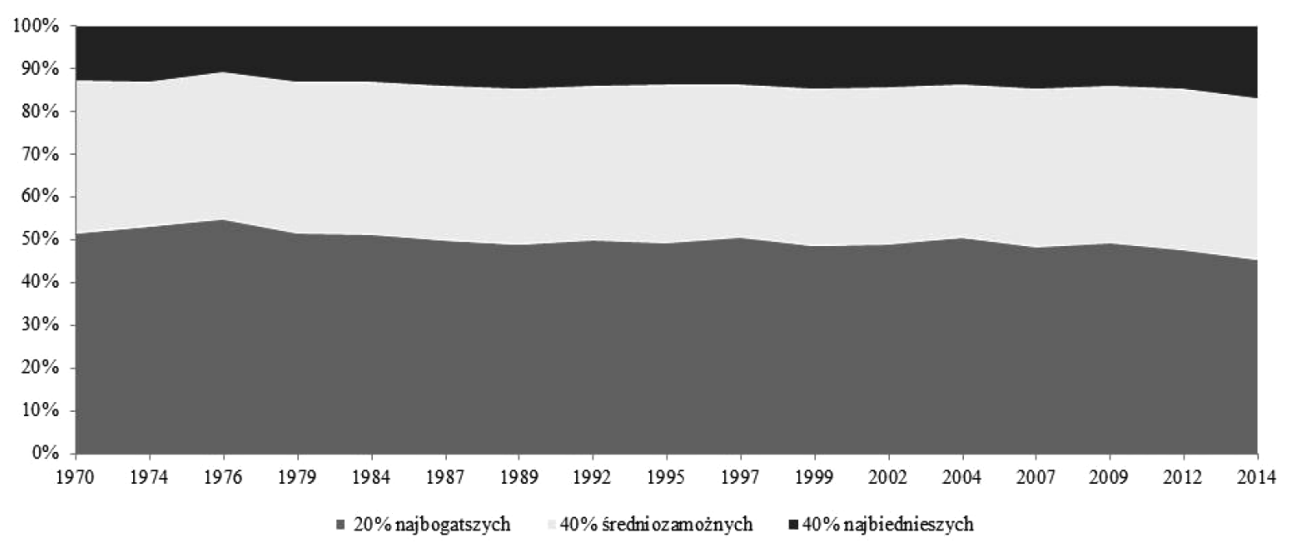

Rys. 2. Zmiany partycypacji w majątku kraju przez Bumiputera z podziałem na trzy grupy dochodowe, 1970-2014

Źródło: opracowanie własne na podstawie Economic Planning Unit, wyd. cyt.

DWN w zakresie redukcji nierówności i ubóstwa był kontynuacją DPN. Problem ubóstwa udało się praktycznie całkowicie rozwiązać, gdyż w 2014 r. wynosił $0,6 \%$ w skali kraju, a $0,8 \%$ dla Bumiputera. Nie można zapominać jednak, że problem w dalszym ciągu dotyka niektóre wykluczone grupy ludności autochtonicznej. Wskaźnik nierówności systematycznie maleje, jednak nierówności wewnątrz grup nie maleją proporcjonalnie szybko.

\subsection{Współczesne programy rozwoju}

W marcu 2010 r. rząd Malezji wprowadził nowy długoterminowy program rozwojowy: Nowy Model Gospodarczy (Model Ekonomi Baru, MEB), którego realizacja przeznaczona jest na dziesięć lat (2010-2020). Mimo że problem ubóstwa został praktycznie rozwiązany, to jednak autorzy programu zwracają uwagę, że ok. $40 \%$ gospodarstw domowych operuje miesięcznym dochodem wynoszącym poniżej 1500 RM. Podobnie jest z nierównościami ekonomicznymi. Mimo że przez dekady udało się je zmniejszyć w skali kraju z 0,513 w 1970 r. do 0,401 w 2014 r. (tab. 3) to rządzący zdają sobie sprawę z problemu rozwarstwienia między najuboższymi a najbiedniejszymi.

MEB wspólnie z X i XI planem gospodarczym ma skoncentrować się na niwelowaniu tego problemu m.in. przez włączenie kolejnych grup wykluczonych w partycypowaniu w majątku kraju, osiągnięcie do 2020 r. PKB per capita na poziomie 15 000-20 000 USD, wzmocnienie instytucji publicznych czy zredukowaniu różnic ekonomicznych między regionami kraju ${ }^{60}$.

${ }^{60}$ National Economic Advisory Council, New Economic Model for Malaysia, Kuala Lumpur 2010. 
Tabela 3. Współczynnik Giniego z rozróżnieniem na grupy etniczne Malezji, 1970-2014

\begin{tabular}{|c|c|c|c|c|c|c|c|c|c|c|c|c|}
\hline & \multicolumn{5}{|c|}{$\begin{array}{l}\text { Nowa Ekonomia } \\
\text { Polityczna (DEB) }\end{array}$} & & \multicolumn{2}{|c|}{$\begin{array}{l}\text { Azjatycki } \\
\text { kryzys } \\
\text { finansowy }\end{array}$} & & & & \\
\hline & 1970 & 1976 & 1979 & 1987 & 1989 & 1992 & 1997 & 1999 & 2002 & 2007 & 2009 & 2014 \\
\hline Malezja & 0,513 & 0,557 & 0,505 & 0,456 & 0,446 & 0,459 & 0,459 & 0,443 & 0,461 & 0,441 & 0,441 & 0,401 \\
\hline Bumiputera & 0,466 & 0,506 & 0,468 & 0,447 & 0,429 & 0,442 & 0,448 & 0,433 & 0,435 & 0,43 & 0,44 & 0,389 \\
\hline Chińczycy & 0,466 & 0,541 & 0,474 & 0,428 & 0,419 & 0,42 & 0,416 & 0,434 & 0,455 & 0,432 & 0,425 & 0,405 \\
\hline Hindusi & 0,472 & 0,509 & 0,46 & 0,402 & 0,39 & 0,402 & 0,409 & 0,413 & 0,399 & 0,414 & 0,424 & 0,396 \\
\hline
\end{tabular}

Źródło: Economic Planning Unit, wyd. cyt.

\section{Konkluzje}

Badacze przedstawiają wiele przyczyn nierówności dochodowych na świecie. Jednakże najbardziej adekwatnych do aktualnej sytuacji Malezji jest pięć z nich ${ }^{61}$ :

- wolniejszy wzrost rolnictwa w porównaniu z innymi sektorami gospodarki,

- zglobalizowany handel,

- utrudniona wewnętrzna migracja,

- zróżnicowanie regionalne i niesymetryczny wzrost jednych regionów względem drugich,

- uwarunkowania historyczne.

Malezja m.in. dzięki wdrożonym długoterminowym programom rozwojowym poradziła sobie z problemem rozwarstwienia ekonomicznego i ogromnym ubóstwem w czasie kilku dekad. W 2012 r. współczynnik Giniego wynosił 0,431 i plasuje to Malezję wśród takich krajów, jak Kenia, Nigeria czy Filipiny. Nie jest to więc pozycja adekwatna dla tak silnej gospodarki o rozwiniętej infrastrukturze i instytucjach. Najważniejsze działania, które można zarekomendować rządowi Malezji, to m.in. ${ }^{62}$ :

- koncentracja na wyrównywaniu relacji między miastem a terenami wiejskimi oraz pomiędzy regionami; w przypadku grup etnicznych Malezja powinna skoncentrować się na rozwarstwieniu wewnątrz grup, szczególnie 40\% grupie najbiedniejszych;

- łatwiejszy dostęp do edukacji dla najbiedniejszych, bez względu na pochodzenie etniczne;

- stworzenie sprawiedliwego systemu podatkowego, który zapewni redystrybucję środków od najbogatszych do najbiedniejszych obywateli;

- wzmocnienie instytucji formalnych, które stworzą właściwe i efektywne środowisko dla niwelowania rozwarstwienia ekonomicznego.

${ }^{61}$ Zob. np. H. Ragayah, wyd. cyt., s. 128.

${ }^{62}$ Tamże, s. 129. 
W dalszym ciągu przed Malezyjczykami stoi wiele wyzwań. Ze względu na w pewnym sensie dyskryminacyjny charakter wdrożonych polityk, czego szczególnym przykładem jest DEB, niektórzy ekonomiści twierdzą, że należy zerwać z polityką opartą na tworzeniu przywilejów dla grup etnicznych. Należy skoncentrować się na niwelowaniu rozwarstwienia ekonomicznego między najbogatszymi a resztą społeczeństwa ${ }^{63}$. Mimo że rozwarstwienie ekonomiczne między grupami etnicznymi udało się zmniejszyć, to nierówności polityczne i społeczne, które rosły przez lata, pozostają ogromnym problemem kraju. W skrajnej sytuacji może przerodzić się to w wybuch przemocy o charakterze politycznym, jaki nastąpił w $1969 \mathrm{r}$.

\section{Literatura}

A dangerous result, The Economist 2013, http://www.economist.com/news/leaders/21577390-aftertainted-election-victory-najib-razak- needs-show-his-reformist-mettle-dangerous (13.09.2015).

Abdullah A.J., Doucouliagos H., Manning E., Are regional incomes in Malaysia converging?, Papers in Regional Science 2015, vol. 94, s. 69-94.

Associated Press, Malaysia's election result exposes divided country, CBCNews, 2013, http://www. cbc.ca/news/world/malaysia-s-election-result-exposes-divided-country-1.1344840 (13.09.2015).

Bank Negara Malaysia, Malaysia's Total Trade by Market, http://www.bnm.gov.my/files/publication/ ar/en/2014/zcp07_table_A.12.pdf(13.09.2015).

Department of Statistics Malaysia, Population Distribution and Basic Demographic Characteristic 2010, Putrajaya, 2011.

Economic Planning Unit, Malaysia: 30 Years of Poverty Reduction, Growth and Racial Harmony, 2004, http://web.worldbank.org/archive/website00819C/WEB/PDF/MALAYS-2.PDF (13.09.2015).

Gomez E., Affirmative action and enterprise development in Malaysia: The New Economic Policy, Business Partnership and Inter-ethnic Relations Kajian Malaysia 2003, vol. 21, no. 1/2, s. 59-104.

Jastrzębska W., Lechwar M., Nierówności ekonomiczne i kapitat ludzki z perspektywy polskich obszarów przyrodniczo cennych, Nierówności Społeczne a Wzrost Gospodarczy nr 24, Uniwersytet Rzeszowski, Rzeszów 2012.

Jomo K., The New Economic Policy and Interethnic Relations in Malaysia, Identities, Conflict and Cohesion Program Paper 2004, no. 7, United Nations Research Institute for Social Development.

Khoo B., Ethnic Structure, Inequality and Governance in the Public Sector Malaysian Experiences, Democracy, Governance and Human Rights Programme Paper 20, 2005, http://www.unrisd.org/80256B3C005BCCF9/\%28httpAuxPages\%29/19309421DF6D65D3C12570FA00392E12/\$ file/Khoo\%20\%28small\%29.pdf (31.03.2015).

Kuznets S., Economic growth and income inequality, The American Economic Review 1955, vol. 45, no. 1, s. $1-28$.

Lahiri D., Malaysian Indian Community: Victim of 'Bumiputera' Policy, ORF Issue Brief 2008, no. 12, s. $1-8$.

Lim I., Economist: NEP has outlived its relevance, Malaysia must end it to progress, Malay Mail Online, 2015, www.themalaymail.online.com/Malaysia/article/economist-nep-hasoutlived-its-relevance-malaysia-must-end-it-to-progress (13.09.2015).

${ }^{63}$ I. Lim, Economist: NEP has outlived its relevance, Malaysia must end it to progress, Malay Mail Online, 2015, www.themalaymail.online.com/Malaysia/article/economist-nep-hasoutlived-itsrelevance-malaysia-must-end-it-to-progress (13.09.2015). 
Malaysian External Trade Development Corporation, Top 10 Major Export Products 2014, http://www. matrade.gov.my/en/malaysia-exporters-section/33-trade-statistics/3184-top-10-major-exportproducts-2014 (13.09.2015).

Malaysian Indian Minority and Human Rights Violations Annual Report 2008, http://www.indianmalaysian.com/MalaysianIndianReport.pdf (13.09.2015).

Masron T., Fujimaki M., Norhasimah I., Orang Asli in peninsular Malaysia: Population, spatial distribution and socio-economic conditions, Journal of Ritsumeikan Social Sciences and Humanities 2013, vol. 6, s. 75-115.

Nagel T., Pytania ostateczne, Fundacja Aletheia, Warszawa 1997.

National Economic Advisory Council, , New Economic Model for Malaysia, Kuala Lumpur 2010.

Osman Z., Shahiri H., Ethnic and gender inequality in employment during New Economic Policy, Institutions and Economics 2014, vol. 6, no. 1, s. 57-72.

Piketty T., Kapitat w XXI wieku, Wydawnictwo Krytyki Politycznej, Warszawa 2015.

Piotrowska M., Rola instytucji w redukowaniu ubóstwa, [w:] B. Klimczak (red.) Mikroekonomia i ekonomia instytucjonalna, Prace Naukowe Uniwersytetu Ekonomicznego we Wrocławiu nr 74, Ekonomia 3, Wydawnictwo Uniwersytetu Ekonomicznego we Wrocławiu, Wrocław 2009, s. 172-181.

Ragayah H., Income inequality in Malaysia, Asian Economic Policy Review 2008, vol. 3, no. 1, s. $114-132$.

Rawls J., Teoria sprawiedliwości, Wydawnictwo Naukowe PWN, Warszawa 1994.

Sen A., Nierówności. Dalsze rozważania, Społeczny Instytut Wydawniczy Znak, Kraków 2000.

Undang-Undang Malaysia, Perlembagaan Persekutuan, 2006, http://www.jac.gov.my/images/stories/ akta/perlembagaanpersekutuan.pdf (19.02.2016).

Woźniak W., Politycy szczebla centralnego i lokalne elity wobec kwestii dziedziczenia nierówności społecznych, Praca doktorska, Uniwersytet Łódzki, Łódź 2011, http://dspace.uni.lodz.pl:8080/xmlui/ handle/11089/7125 (13.09.2015). 